\title{
Effects of Annual Ring Number and Width on Ultrasonic Waves in Some Softwood Species
}

\begin{abstract}
Murat Aydin
The effect of annual ring number and width on the longitudinal $(P)$ and transverse (S) ultrasonic wave velocities in the radial direction of black pine, Scots pine, Turkish red pine, and cedar softwoods was evaluated in this study. Annual rings were evaluated using high-resolution images captured with a Lumix camera. The $2.25 \mathrm{MHz} \mathrm{P}$ and $1 \mathrm{MHz} \mathrm{S}$ wave frequencies were propagated through the radial direction of small clear samples. An increase in ring number caused different changes in the $\mathrm{P}$ and $S$ wave velocities. Only Scots pine and cedar presented continuous decreases in $\mathrm{P}$ and $\mathrm{S}$ wave velocities with the increase in annual rings. On the contrary, $V_{\mathrm{R}}$ of Red pine slightly decreased and surpassed the initial value when the ring numbers increased from 5 to 10 and 15, respectively. Furthermore, the greatest decrease $(4 \%)$ in the velocities was observed for $V_{\mathrm{RL}}$ of Red pine. According to one-way ANOVA results, significant relations were only observed for $V_{R} v s$. ring number of Black pine and cedar. $R^{2}$ values ranged from 0.0001 (Red pine $V_{R}$ ) to 0.18 (Cedar $V_{R}$ ) for ring number and 0.0002 (Cedar $V_{R}$ ) to 0.44 (Scots pine $V_{R}$ ) for ring width. Furthermore, ANOVA results for linear regression analysis showed that $V_{R}$ of Scots pine and $V_{\mathrm{R}}, V_{\mathrm{RL}}, V_{\mathrm{RT}}$ of Red pine can be statistically significantly predicted by the ring widths.
\end{abstract}

DOI: 10.15376/biores.17.1.1745-1763

Keywords: Annual rings; Ultrasound; Velocity; Softwood

Contact information: Department of Machine, Keçiborlu Vocational School, Isparta University of Applied Sciences, Isparta, Turkey; *Corresponding author: murataydin@isparta.edu.tr

\section{INTRODUCTION}

Ultrasonic testing is an evaluation method that is relatively less laboratorydependent than other methods and that can be applied in various fields. Prominent properties of this type of testing include mobility and compatibility. However, interpretation of the ultrasonic signal is not easy, and an experienced user is needed for using the tools in manual mode. Also, the reproducibility of ultrasonic evaluation seems limited in manual mode. Therefore, operator-independent automated systems reduce the errors caused by misreading by the experienced or inexperienced user and improve the signal-to-noise ratio (Gros 1997). Interpretation of signals in wood science becomes more complicated due to the complex structure of wood material that presents different properties through the essential axis and planes. The anisotropic and inhomogeneous material structure of wood greatly attenuates ultrasound due to scattering from the inhomogeneity variations in the microstructure (Berndt and Johnson 1995). Therefore, an ultrasonic beam attenuates due to variation in composition, density, and porosity of the material (Gros 1997). Furthermore, these properties change due to environmental conditions and cause variations within the species that are much more complex than 
anisotropy (Brancheriau et al. 2012). The cellular microstructure of wood and the nanostructure of the cell walls control the elastic properties. Furthermore, the properties of wood are maximized in the longitudinal (L) direction (Ansell 2015). The same is true for ultrasonic wave velocities (UWV) in wood, and according to Dackermann et al. (2014), radial and tangential wave velocities are generally about a third of the longitudinal wave. Similar behavior is true for shear or transverse wave velocities, and transverse wave velocities of wood are remarkably slower than the longitudinal waves. These significant differences occur because of the longitudinally aligned anatomical elements such as fibers and tracheid, and radially aligned wood rays in growth rings. However, such structural elements are not observable through the tangential direction. When the polar orthotropic nature of wood is taken into consideration, the propagation of ultrasonic waves encounters these variations. Furthermore, micro-fibril angle and the length of the anatomical elements have influences on variations. For example, a small cell wall layer is responsible for higher acoustic wave velocities (Bergander and Salmén 2000). More comprehensive data for the propagation and distribution properties of longitudinal and transverse ultrasound waves in wood and wood-based materials are provided by Bucur (2006).

Changes in environmental factors may have essential effects on the anatomical properties of wood. One of the essential variations in wood structure is the annual rings (ARs) due to environmental factors in normal growth or engineered growth by sylvicultural practices. Tree-rings enclose the history of all experiences or developments that take place in the surrounding area within the tree stem. According to Carrer (2011), tree-rings are a valuable source of information due to the characteristics they have earned year by year. Many studies have evaluated tree-ring-related issues, and the fundamentals of the tree-ring research and evaluation are thoroughly presented by Schweingruber (1988) and Speer (2012). A hand lens with a scale is the simplest optical instrument for measuring the treerings. However, advanced tools, hardware, and software are the leading development for the evaluation of tree-ring and it's effects on the properties. For example, Jackson et al. (2009) evaluated the ring-growth patterns of many wood specimens by terahertz timedomain reflectometry. Perlin et al. (2019) conducted an ultrasonic tomography investigation of timber slices through the tangential and radial directions regarding the growth ring direction. Mori et al. (2019) developed a non-destructive RW measurement technique and evaluated the effectiveness over the archaeologically excavated waterlogged wood. Adamopolous et al. (2009) determined the relationship between the ring-width (RW) and stem height for Pinus brutia using LINTAB and TSAP-Win. Trouillier et al. (2018) used optical scans and CooRecorder for RW measurements and CDendro for crossdating of white spruce. Shishkova and Panayotov (2013) used CooRecorder and CDendro to measure and cross-date the tree-widths of Pinus nigra, respectively.

Knapic et al. (2007) investigated the relation between RW, the number of rings, density, and cambial age properties of oak wood. Kharrat et al. (2019) evaluated the RW, density, and modulus of elasticity (MOE) variations for black spruce and Jack pine woods using UWV measurement in terms of 5, 10, 15, and 20 annual ring numbers (ARNs) from the pith. They stated that the correlation between density and dynamic MOE is positive and statistically significant in rings. Dackermann et al. (2016) reported that AR acts as a barrier against waves and decreases the velocity of waves. Effects of inter and intra-tree (ring) variations were evaluated before. However, a comparison between the trees should be made over the same number of AR instead of similar size or diameter because results tend to be similar (Bendtsen 1978). From this point of view, figuring out the influence of AR on the ultrasonic wave by the same number instead of using the same sample size was 
aimed in this study. Consequently, this study tried to determine the effect of ARN and annual ring width (ARW) on the longitudinal and transverse UWV in the radial direction of four different softwood species in terms of the same number of rings.

\section{EXPERIMENTAL}

\section{Materials and Methods}

Black pine (Pinus nigra Arnold.), Scots pine (Pinus sylvestris L.), Turkish red pine (Pinus brutia Ten.), and cedar (Cedrus libani A. Rich.) woods were used in this study. Samples for each species were prepared with at least 5, 10, and 15 ARs. As seen in Figs. 1 and 2, samples were prepared according to the ARN instead of a certain dimension through the radial direction. Therefore, the dimensions of the samples in radial direction were different not only within the species but also between the species. The tangential and longitudinal dimensions were the minimum of 20 millimeters due to the diameter of the transverse transducers.

As can be seen in Fig. 1, predetermined cutting lines were marked on the laths by considering the start and finish points of AR. The laths were cut using a newly-sharped circular saw blade. Samples with improper or false rings and rings with compression wood were not tested. All the samples were prepared using only sapwood sections of the planks. Planks were prepared from the sections following the breast height of the logs. Furthermore, all the samples were cut from the same logs to prevent the probable variations dependent on the sampling. A total of 240 samples (20 for each ARN group) were tested.

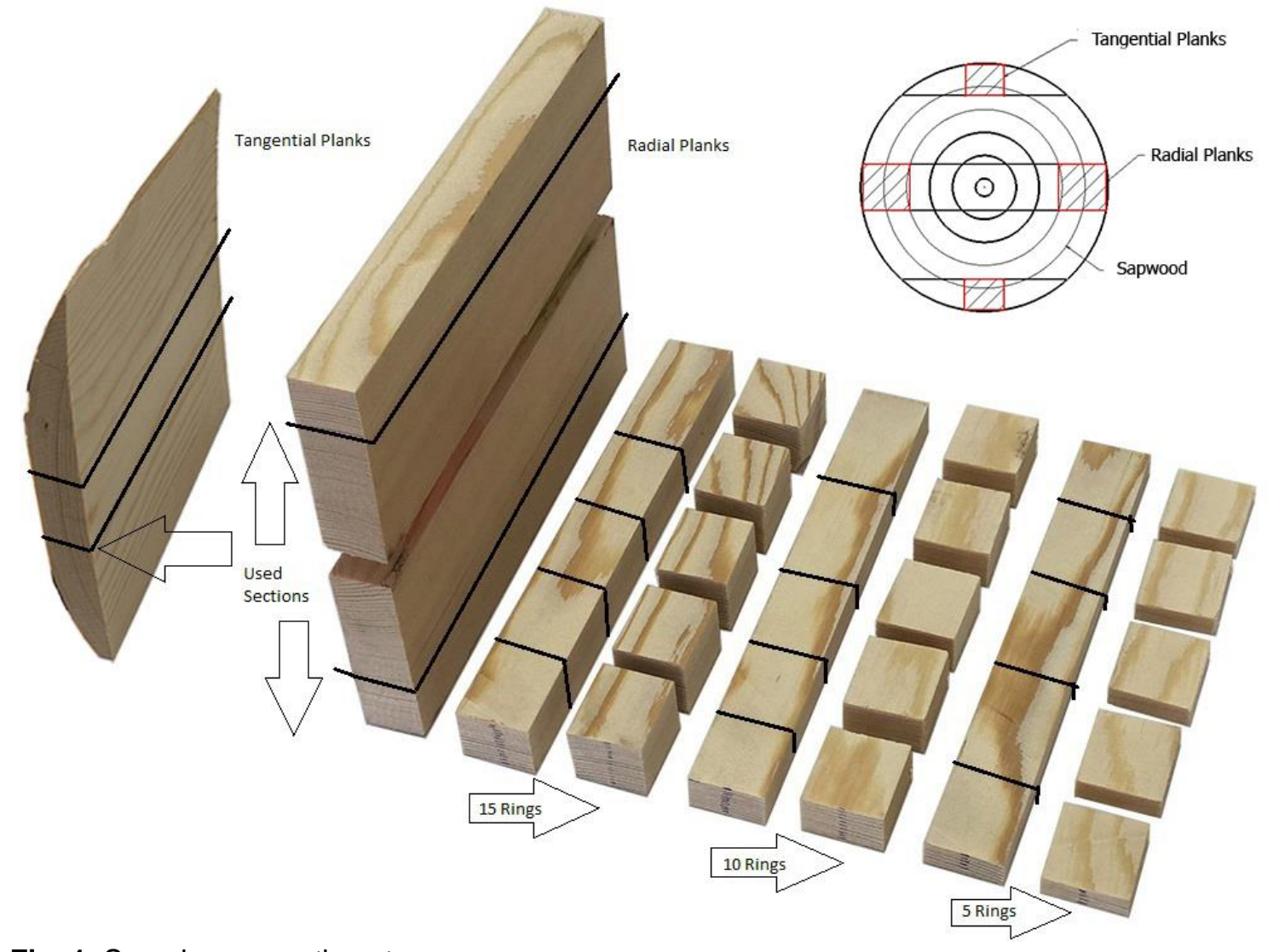

Fig. 1. Sample preparation steps 
Annual ring width (ARW) measurement was performed by image analysis and digital caliper. High-resolution images of the cross-section of the samples were taken using a Lumix GX1 camera and G macro $30 \mathrm{~mm} \mathrm{~F} / 2.8$ lens (Panasonic, Matsushita Electronics, Osaka, Japan). CooRecorder and CDendro (Cybis Elektronik and Data AB, Saltsjöbaden, Sweden) software were used to identify and point the AR borders for growth ring measurements, as seen in Fig. 2.

An Olympus Epoch 650 flaw detector (Olympus, Waltham, MA, USA) was used to measure the time of flight values in micro-second. Relatively high frequencies such as 1 Megahertz (MHz) can be used for the small (around $100 \mathrm{~mm}$ ) specimens (Krause et al. 2015). Bucur and Kazemi-Najafi (2011) reported that $2.25 \mathrm{MHz}$ transducer frequency provides greater energy and penetration into the material. Furthermore, Gonçalves et al. (2011, 2014), Hering et al. (2012), Vázquez et al. (2015), Niemz et al. (2017), Bachtiar et al. (2017), and Luis Gómez-Royuela et al. (2021) are some of the recent studies performed elastic characterization of wood using these central frequencies. Therefore, the effect of AR on UWV in the radial direction has been evaluated using longitudinal $(2.25 \mathrm{MHz})$ and transverse $(1 \mathrm{MHz})$ waves. Longitudinal wave velocity in the radial direction $\left(V_{\mathrm{R}}\right)$, and transverse or shear wave velocities in the Radial direction and Longitudinal ( $\left.V_{\mathrm{RL}}\right)$ or Tangential $\left(V_{\mathrm{RT}}\right)$ polarizations were calculated using the transmitting time of ultrasound waves and dimensions of the samples through the radial direction.
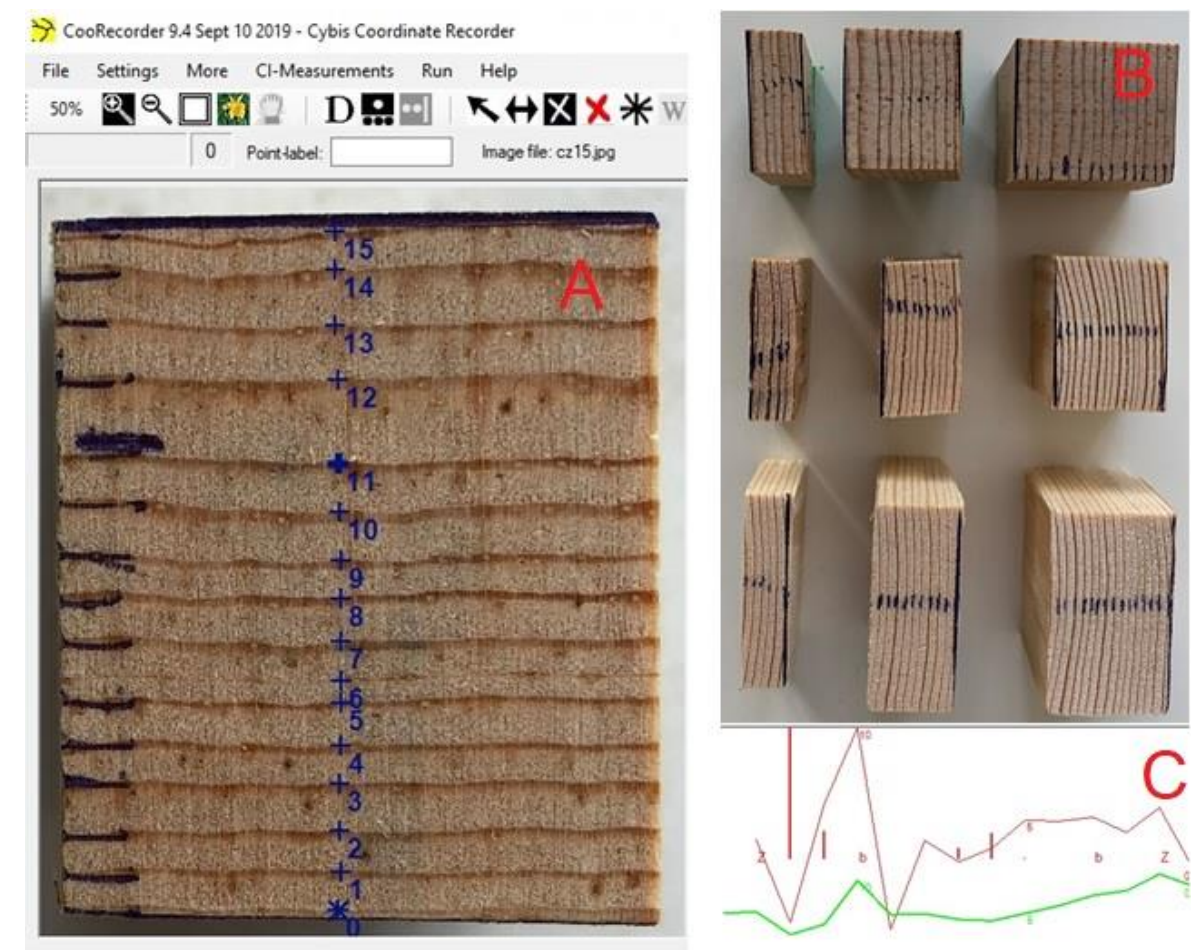

Fig. 2. CooRecorder ring border pointing and RW for red pine $(A)$, radial sections, and $A R$ of the samples (B), and CDendro Plot details for cedar wood (C)

Defect-free samples were conditioned at $65 \%$ relative humidity and $20 \pm 1{ }^{\circ} \mathrm{C}$ temperature. Densities were determined according to TS 2472 (2005) standard by stereometric method (dimension and weigh measurement using a digital caliper and precision scale, respectively).

One-way Analysis of Variance (ANOVA) was performed to interpret the effect of 
ARNs on velocities. Duncan's multiple range (DMR) test was conducted to figure out the differences between the mean values of ARN groups. The confidence interval was $95 \%$. The coefficients of determination $\left(\mathrm{R}^{2}\right)$ by linear regression analysis were calculated to evaluate how differences in UWV can be expressed by ARW and ARN.

\section{RESULTS AND DISCUSSION}

The average values of ARW, density and UWV are presented in Table 1 . The widths of the annual tree-ring strictly depend on the growth conditions. Temperature and precipitation are the responsible factors for the variations in tree-ring width (Dogan and Kose 2019). In general, widths are positively correlated with the amount of summer precipitation (Haneca et al. 2009), and it's expected that location and environmental factors may make great variations in the ring properties. As can be seen in the table, variations for the ARW ranged from 7.7 to 17.6\%. Reported variations for ARW were 20.4\% (Mederski et al. 2013), 42.3\% (Fabisiak and Fabisiak 2021), 15.3\% (total chronology from 19582016) (Özel et al. 2021), and 60.5\% (Büyüksari et al. 2017) for Scots pine, 40.8\% (total chronology from 1970 to 2011) (Kantarci et al. 2013), 17.8 to 35.2\% (Doğan and Köse 2015) for black pine, 39.2\% (Adamopoulos et al. 2009) for red pine (Pinus brutia Ten.), and $60.9 \%$ (Öktem and Sözen 1992) for Cedrus libani. When compared to the reported data, it's thought that relatively fewer variations for ARW were obtained due to sample preparations because samples were cut from the outer section of the matching planks, as mentioned in the experimental.

Variations in the ARW are to be expected due to climate changes. As noted by Köse et al. (2012), year-by-year alterations in environmental factors cause discrepancies in treering widths, and in the literature, great varieties of ARW were reported for tested species. For example, variations of approximately 0.25 to $1.8 \mathrm{~mm}$ (Kemalpaşa Mountain) and from 1 to $6 \mathrm{~mm}$ (Karabelen Mountain) were observed for Pinus brutia Ten through 1942 to 1998 period (Tolunay 2003). Therefore, great variations in ARW are possible not only due to the growth conditions and region but also by the periods. Therefore, ARWs can be in accordance with the literature or not due to lots of affecting factors. However, as can be seen in Table 1, ARW averages of Scotch pine wood ranged from 1.26 to $1.37 \mathrm{~mm}$, which are in accordance with $1.34 \mathrm{~mm}$ reported by Büyüksarı et al. (2017) and in the range of 0.79 to $2.6 \mathrm{~mm}$ and 0.37 to $3.91 \mathrm{~mm}$ reported by Dündar (2005) and Sensuła et al. (2017), respectively. Similar harmonies are valid for black pine such as 0.11 to $4.82 \mathrm{~mm}$ (from 1744 to 2011 - Hodul Mountain) (Kantarci et al. 2013), and cedar woods such as 2.45 to $4.11 \mathrm{~mm}$ (Akkemik 2003).

According to results shown in Table 1, all longitudinal and transverse wave velocities were decreased when ARNs were increased from five to ten. However, $V_{R}$ of red pine, $V_{\mathrm{RL}}$ of black pine, and $V_{\mathrm{RT}}$ of red pine were increased when ARN was increased from 10 to 15 . However, almost all increased values were below the average of the initial values except $V_{\mathrm{R}}$ of red pine. The $V_{\mathrm{R}}$ of red pine slightly surpassed $(0.1 \%)$ the initial value, but it was just $2 \mathrm{~m} / \mathrm{s}$ and can be regarded as negligible. Also, $V_{\mathrm{RT}}$ of red pine and cedar for 10 and 15 rings were almost equal. Therefore, constant but various decreases in all velocities by the increase in ARN were observed only for Scots pine and cedar.

The maximum decrease $(-4.0 \%)$ in the velocity was seen in the transverse ultrasonic wave of red pine. The changes in longitudinal wave velocities with the increase in ARN ranged from $-3.7 \%$ (black pine, 15 rings) to $+0.1 \%$ (red pine, 15 rings). Decreases in $V_{\mathrm{RL}}$ 
ranged from $-4 \%$ (red pine, 15 rings) to -0.8 (red pine, 10 rings). Decreases in $V_{\mathrm{RT}}$ ranged from $-3.7 \%$ (black pine, 15 rings) to -0.5 (Scots pine, 10 rings). The tendencies of $V_{\mathrm{RL}}$ and $V_{\mathrm{RT}}$ for red pine and Scots pine were nearly the same. Moreover, velocities decreased more specifically following the ten AR, except $V_{\mathrm{RL}}$ for black pine.

Table 1. Average ARW, Density, UWV Values of the Species

\begin{tabular}{|c|c|c|c|c|c|c|c|c|}
\hline Species & ARN & $\begin{array}{c}\text { Sample } \\
\text { Size }\end{array}$ & & $\begin{array}{l}\text { ARW } \\
(\mathrm{mm})\end{array}$ & $\begin{array}{l}\text { Density } \\
\left(\mathrm{kg} / \mathrm{m}^{3}\right)\end{array}$ & $\begin{array}{c}V_{R} \\
(\mathrm{~m} / \mathrm{s})\end{array}$ & $\begin{array}{c}V_{\mathrm{RL}} \\
(\mathrm{m} / \mathrm{s})\end{array}$ & $\begin{array}{c}V_{\mathrm{RT}} \\
(\mathrm{m} / \mathrm{s})\end{array}$ \\
\hline \multirow{9}{*}{$\begin{array}{l}\text { Scots } \\
\text { pine }\end{array}$} & \multirow[t]{3}{*}{5} & \multirow{3}{*}{20} & Avg & 1.37 & 512 & 1625 & 1068 & 691 \\
\hline & & & Std.D. & 0.20 & 22.01 & 88.96 & 86.08 & 50.21 \\
\hline & & & CoV (\%) & 14.77 & 4.30 & 5.47 & 8.06 & 7.26 \\
\hline & \multirow[t]{3}{*}{10} & \multirow[t]{3}{*}{20} & Avg & 1.29 & 517 & $1605(-1.3)^{*}$ & $1060(-0.8)$ & $688(-0.5)$ \\
\hline & & & Std.D. & 0.10 & 23.83 & 88.94 & 98.65 & 43.37 \\
\hline & & & CoV (\%) & 7.74 & 4.61 & 5.54 & 9.31 & 6.30 \\
\hline & \multirow[t]{3}{*}{15} & \multirow[t]{3}{*}{20} & Avg & 1.26 & 516 & $1589(-2.2)$ & $1047(-2.0)$ & $673(-2.6)$ \\
\hline & & & Std.D. & 0.18 & 30.36 & 80.42 & 77.32 & 53.20 \\
\hline & & & CoV (\%) & 13.93 & 5.88 & 5.06 & 7.38 & 7.90 \\
\hline \multirow{9}{*}{$\begin{array}{l}\text { Red } \\
\text { pine }\end{array}$} & \multirow[t]{3}{*}{5} & \multirow[t]{3}{*}{20} & Avg & 1.20 & 551 & 1967 & 1215 & 723 \\
\hline & & & Std.D. & 0.16 & 11.70 & 62.01 & 95.03 & 40.55 \\
\hline & & & $\operatorname{CoV}(\%)$ & 13.61 & 2.12 & 3.15 & 7.82 & 5.61 \\
\hline & \multirow[t]{3}{*}{10} & \multirow[t]{3}{*}{20} & Avg & 1.13 & 544 & $1953(-0.7)$ & $1205(-0.8)$ & $717(-0.9)$ \\
\hline & & & Std.D. & 0.17 & 10.16 & 81.44 & 89.82 & 52.82 \\
\hline & & & CoV (\%) & 15.26 & 1.87 & 4.17 & 7.45 & 7.37 \\
\hline & \multirow[t]{3}{*}{15} & \multirow[t]{3}{*}{20} & Avg & 1.17 & 542 & 1969 (+0.1) & $1166(-4.0)$ & $717(-0.8)$ \\
\hline & & & Std.D. & 0.21 & 12.91 & 117.11 & 100.93 & 40.03 \\
\hline & & & $\operatorname{CoV}(\%)$ & 17.60 & 2.38 & 5.95 & 8.65 & 5.58 \\
\hline \multirow{9}{*}{$\begin{array}{l}\text { Black } \\
\text { pine }\end{array}$} & \multirow[t]{3}{*}{5} & \multirow[t]{3}{*}{20} & Avg & 1.49 & 560 & 1863 & 1224 & 640 \\
\hline & & & Std.D. & 0.40 & 11.65 & 94.94 & 72.32 & 44.19 \\
\hline & & & $\operatorname{CoV}(\%)$ & 16.02 & 2.08 & 5.10 & 5.91 & 6.90 \\
\hline & \multirow[t]{3}{*}{10} & \multirow[t]{3}{*}{20} & Avg & 1.53 & 547 & $1816(-2.6)$ & $1179(-3.7)$ & $623(-2.7)$ \\
\hline & & & Std.D. & 0.22 & 22.52 & 77.47 & 84.51 & 33.47 \\
\hline & & & $\operatorname{CoV}(\%)$ & 14.45 & 4.11 & 4.27 & 7.17 & 5.38 \\
\hline & \multirow[t]{3}{*}{15} & \multirow[t]{3}{*}{20} & Avg & 1.56 & 543 & $1794(-3.7)$ & $1200(-1.9)$ & $617(-3.7)$ \\
\hline & & & Std.D. & 0.18 & 18.77 & 42.80 & 95.07 & 34.57 \\
\hline & & & $\operatorname{CoV}(\%)$ & 11.57 & 3.46 & 2.39 & 7.92 & 5.60 \\
\hline \multirow[t]{9}{*}{ Cedar } & \multirow[t]{3}{*}{5} & \multirow[t]{3}{*}{20} & Avg & 3.21 & 498 & 1861 & 1210 & 1076 \\
\hline & & & Std.D. & 0.28 & 21.25 & 38.79 & 52.00 & 81.36 \\
\hline & & & $\operatorname{CoV}(\%)$ & 8.85 & 4.27 & 2.08 & 4.30 & 7.56 \\
\hline & \multirow[t]{3}{*}{10} & \multirow[t]{3}{*}{20} & Avg & 3.23 & 501 & $1825(-2.0)$ & $1190(-1.6)$ & $1053(-2.1)$ \\
\hline & & & Std.D. & 0.36 & 16.05 & 51.52 & 68.12 & 92.99 \\
\hline & & & $\operatorname{CoV}(\%)$ & 11.03 & 3.20 & 2.82 & 5.73 & 8.83 \\
\hline & 15 & 20 & Avg & 2.93 & 500 & $1808(-2.9)$ & $1180(-2.5)$ & $1052(-2.2)$ \\
\hline & & & Std.D. & 0.45 & 13.96 & 49.72 & 87.21 & 92.66 \\
\hline & & & $\operatorname{CoV}(\%)$ & 15.35 & 2.79 & 2.75 & 7.39 & 8.81 \\
\hline
\end{tabular}

Note: Avg (Average), Std.D. (Standard deviation), CoV (Coefficient of Variation). ${ }^{*}$ Values in parenthesis are the \% differences to five ARs values

The reported $V_{\mathrm{R}}, V_{\mathrm{RL}}$, and $V_{\mathrm{RT}}$ values for the evaluated species are presented in Table 2. Some of the velocities were in harmony, while others were not. However, as reported by Yılmaz Aydın and Küçükköse (2020), ultrasound propagation is a reliable nondestructive test method for the characterization of wood stiffness. 
Table 2. UWV in the Radial Direction

\begin{tabular}{|c|c|c|c|}
\hline \multirow{2}{*}{ Species } & \multicolumn{3}{|c|}{ UWV $(\mathrm{m} / \mathrm{s})$} \\
\hline & $V_{R}$ & $V_{\mathrm{RL}}$ & $V_{\text {RT }}$ \\
\hline Scots pine & 1713 (Akar 2017) & $\begin{array}{c}1105 \text { (Akar 2017) } \\
1863^{\mathrm{a}} \text { (Martinez et al. } \\
\text { 2010) }\end{array}$ & $\begin{array}{c}590(\text { Akar 2017) } \\
1520^{\mathrm{b}} \text { (Martinez et al. 2010) }\end{array}$ \\
\hline Red pine & $\begin{array}{l}2261 \text { (Güntekin et al. } \\
\text { 2015a; b) }\end{array}$ & $\begin{array}{c}1408 \text { (Aydın and Ciritcioglu } \\
2018 \text { ) }\end{array}$ & $\begin{array}{l}666 \text { (Aydın and Ciritcioglu } \\
\text { 2018) }\end{array}$ \\
\hline Black Pine & $\begin{array}{c}1973 \text { (Güntekin and } \\
\text { Yılmaz Aydin 2016), } \\
2128 \text { (Aydın and Yılmaz } \\
\text { Aydın 2020) }\end{array}$ & $\begin{array}{l}1280 \text { (Aydın and Yılmaz } \\
\text { Aydın 2018), } 1370 \text { (Aydın } \\
\text { and Yılmaz Aydın 2020) }\end{array}$ & $\begin{array}{c}423 \text { (Aydın and Yılmaz Aydın } \\
\text { 2018), } 547 \text { (Güntekin and } \\
\text { Yılmaz Aydin 2016), } \\
743 \text { (Aydın and Yılmaz Aydın } \\
\text { 2020) }\end{array}$ \\
\hline Cedar & $\begin{array}{l}2261 \text { (Güntekin et al. } \\
2015 a ; b)\end{array}$ & - & $\begin{array}{l}1449^{\mathrm{c}} \text { (Hasegawa et al. 2016), } \\
1680^{\mathrm{d}} \text { (Hasegawa et al. 2016) }\end{array}$ \\
\hline
\end{tabular}

a,b Transversal ultrasonic velocity in radial and tangential directions obtained by Sylvatest Duo $22 \mathrm{kHz}$, respectively, ${ }^{\mathrm{c}, \mathrm{d}}$ Japanese cedar values for non-contact and contact type measurements, respectively.

The ANOVA results for ARN are presented in Table 3, and changes in the means of UWV due to an increase in ARN were statistically significant only for $V_{R}$ of black pine and cedar woods. According to Duncan's multiple range test classifications (Table 4), there were no statistically significant differences between the means of UWV and ARN except $V_{\mathrm{R}}$ for cedar and black pine species. Furthermore, the mean values of $V_{\mathrm{R}}$ for 10 and 15 rings were statistically the same.

Generally, a high $\mathrm{R}^{2}$ value indicates better prediction of the variable. The values closer to 1 reveal that the association is greater, but do not express the statistical significance. However, according to the results of regression analysis seen through Figs. 3 to 6 , a maximum of $44 \%$ of the data could be predicted by the ARW.
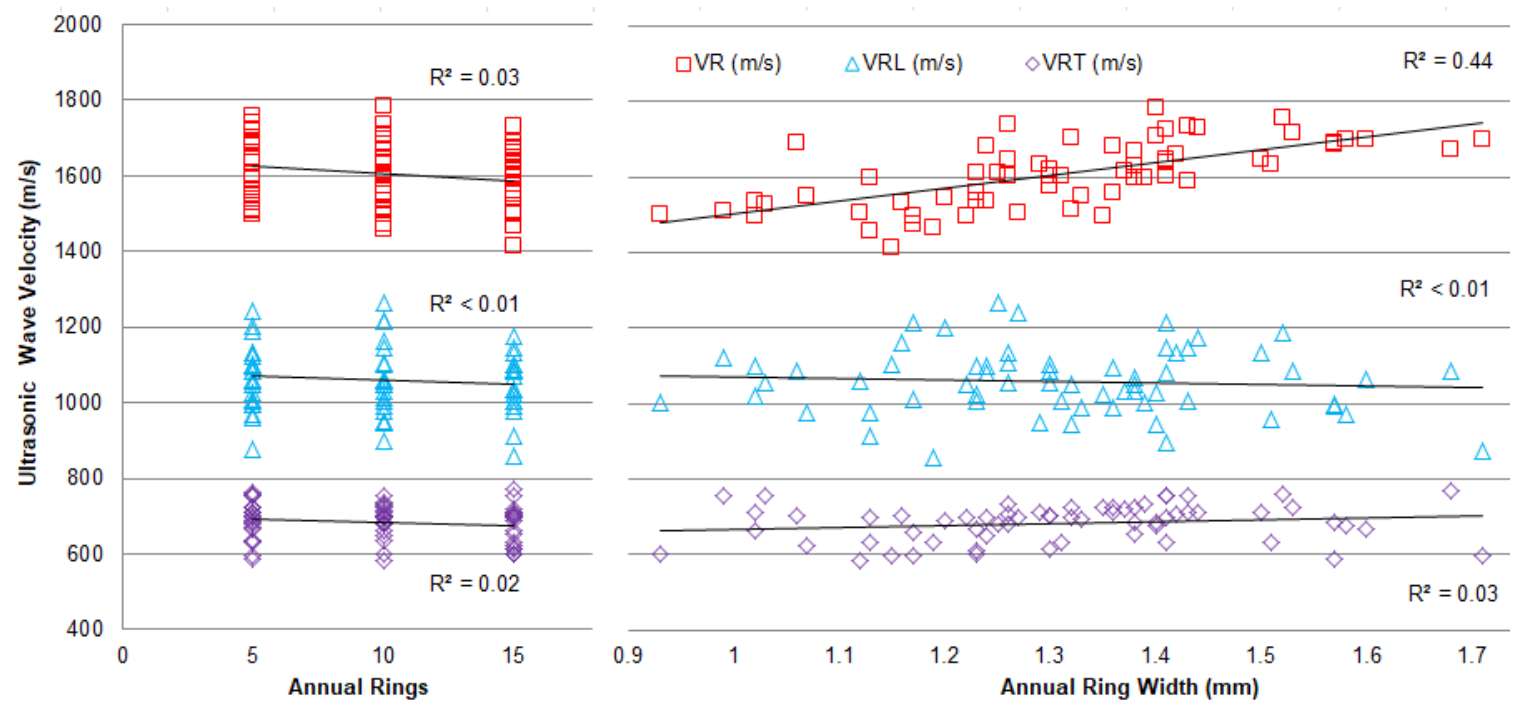

Fig. 3. The relationship between UWV and ARN or ARW for Scots pine 
Table 3. ANOVA Results for ARN

\begin{tabular}{|l|l|l|l|l|l|l|l|l|}
\hline \multicolumn{9}{|c|}{ One-way ANOVA for ARN } \\
\hline \multirow{2}{*}{ Velocities } & Scots Pine & \multicolumn{1}{l|}{ Red Pine } & Black Pine & \multicolumn{2}{l|}{ Cedar } \\
\cline { 2 - 10 } & F & Sig. & F & Sig. & F & Sig. & F & Sig. \\
\hline$V_{\mathrm{R}}$ & 0.947 & 0.394 & 0.173 & 0.842 & 4.446 & 0.016 & 6.716 & 0.002 \\
\hline$V_{\text {RL }}$ & 0.304 & 0.739 & 1.455 & 0.242 & 1.430 & 0.248 & 0.926 & 0.402 \\
\hline$V_{\text {RT }}$ & 0.804 & 0.452 & 0.137 & 0.872 & 2.085 & 0.134 & 0.449 & 0.640 \\
\hline
\end{tabular}

Table 4. Duncan Homogeneity Groups of Ultrasonic Velocities According to ARN

\begin{tabular}{|c|c|c|c|c|c|c|c|c|}
\hline \multirow{2}{*}{ Species } & \multirow{2}{*}{$N$} & \multicolumn{3}{|l|}{$V_{\mathrm{R}}$} & \multicolumn{2}{|l|}{$V_{\mathrm{RL}}$} & \multicolumn{2}{|l|}{$V_{\mathrm{RT}}$} \\
\hline & & ARN & \multicolumn{2}{|l|}{$1^{*}$} & ARN & $1^{*}$ & ARN & $1^{*}$ \\
\hline \multirow{4}{*}{ Scots pine } & 20 & 15 & \multicolumn{2}{|l|}{1588.75} & 15 & 1047.25 & 15 & 673.25 \\
\hline & 20 & 10 & \multicolumn{2}{|l|}{1604.67} & 10 & 1059.76 & 10 & 688.19 \\
\hline & 20 & 5 & \multicolumn{2}{|l|}{1625.27} & 5 & 1068.36 & 5 & 691.41 \\
\hline & & Sig. & \multicolumn{2}{|l|}{.202} & Sig. & .469 & Sig. & .264 \\
\hline & & & & & & & & \\
\hline \multirow{5}{*}{ Red pine } & $\mathrm{N}$ & ARN & \multicolumn{2}{|l|}{$1^{*}$} & ARN & $1^{*}$ & ARN & $1^{*}$ \\
\hline & 20 & 10 & \multicolumn{2}{|l|}{1953.25} & 15 & 1166.45 & 10 & 716.50 \\
\hline & 20 & 5 & \multicolumn{2}{|l|}{1966.50} & 10 & 1205.45 & 15 & 717.45 \\
\hline & 20 & 15 & \multicolumn{2}{|l|}{1968.65} & 5 & 1215.00 & 5 & 723.35 \\
\hline & & Sig. & \multicolumn{2}{|l|}{.614} & Sig. & .134 & Sig. & .653 \\
\hline \multirow{6}{*}{ Black pine } & & & & & & & & \\
\hline & $\mathrm{N}$ & ARN & $1^{*}$ & $2^{*}$ & ARN & $1^{*}$ & ARN & $1^{*}$ \\
\hline & 20 & 15 & 1794.35 & & 10 & 1179.10 & 15 & 616.85 \\
\hline & 20 & 10 & 1815.65 & & 15 & 1200.40 & 10 & 622.70 \\
\hline & 20 & 5 & & 1863.35 & 5 & 1224.25 & 5 & 640.25 \\
\hline & & Sig. & .373 & 1.000 & Sig. & .116 & Sig. & .068 \\
\hline & & & & & & & & \\
\hline \multirow{5}{*}{ Cedar } & $\mathrm{N}$ & ARN & $1^{*}$ & $2^{*}$ & ARN & $1^{*}$ & ARN & $1^{*}$ \\
\hline & 20 & 15 & 1807.75 & & 15 & 1179.75 & 15 & 1052.25 \\
\hline & 20 & 10 & 1824.60 & & 10 & 1189.75 & 10 & 1052.55 \\
\hline & 20 & 5 & & 1861.05 & 5 & 1209.60 & 5 & 1075.55 \\
\hline & & Sig. & .262 & 1.000 & Sig. & .213 & Sig. & .442 \\
\hline
\end{tabular}

$\mathrm{N}$ : sample size, *Subset for alpha $=0.05$ 

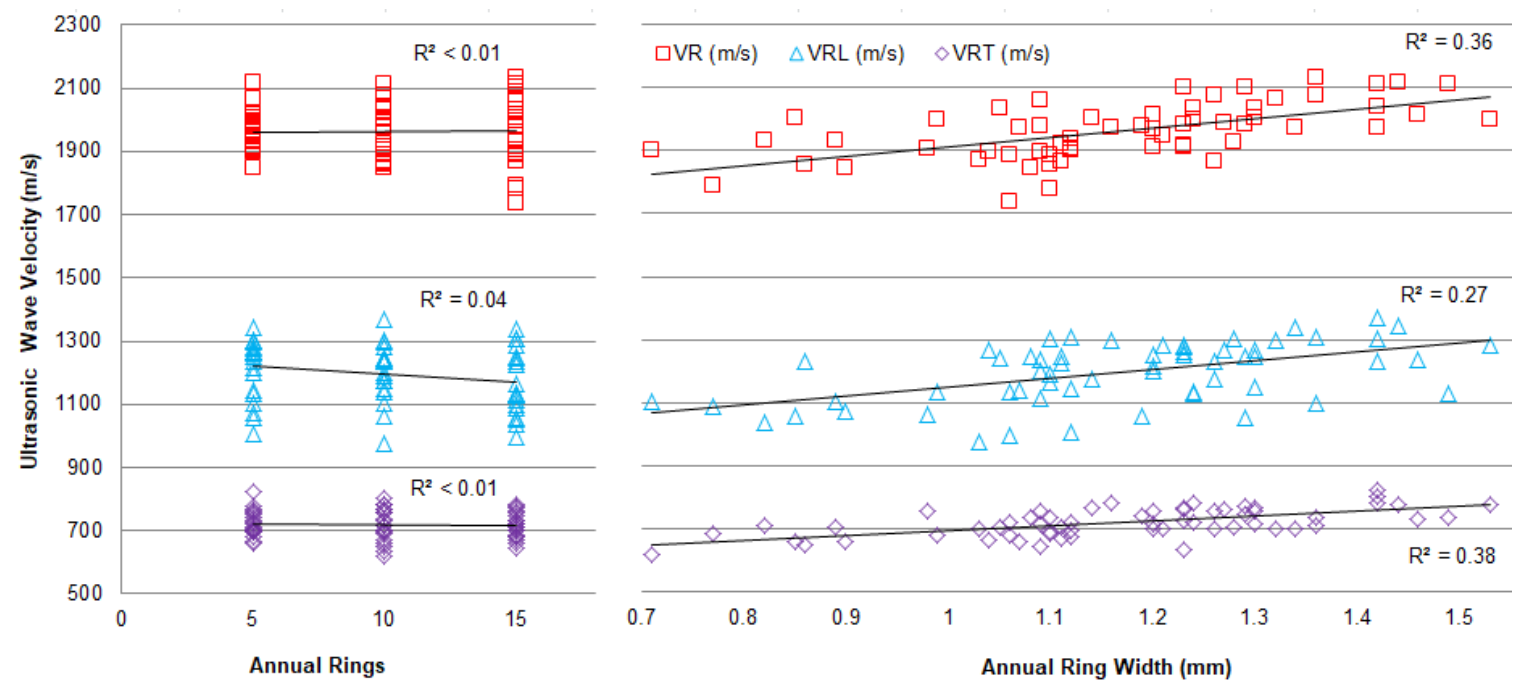

Fig. 4. The relationship between UWV and ARN or ARW for Red pine
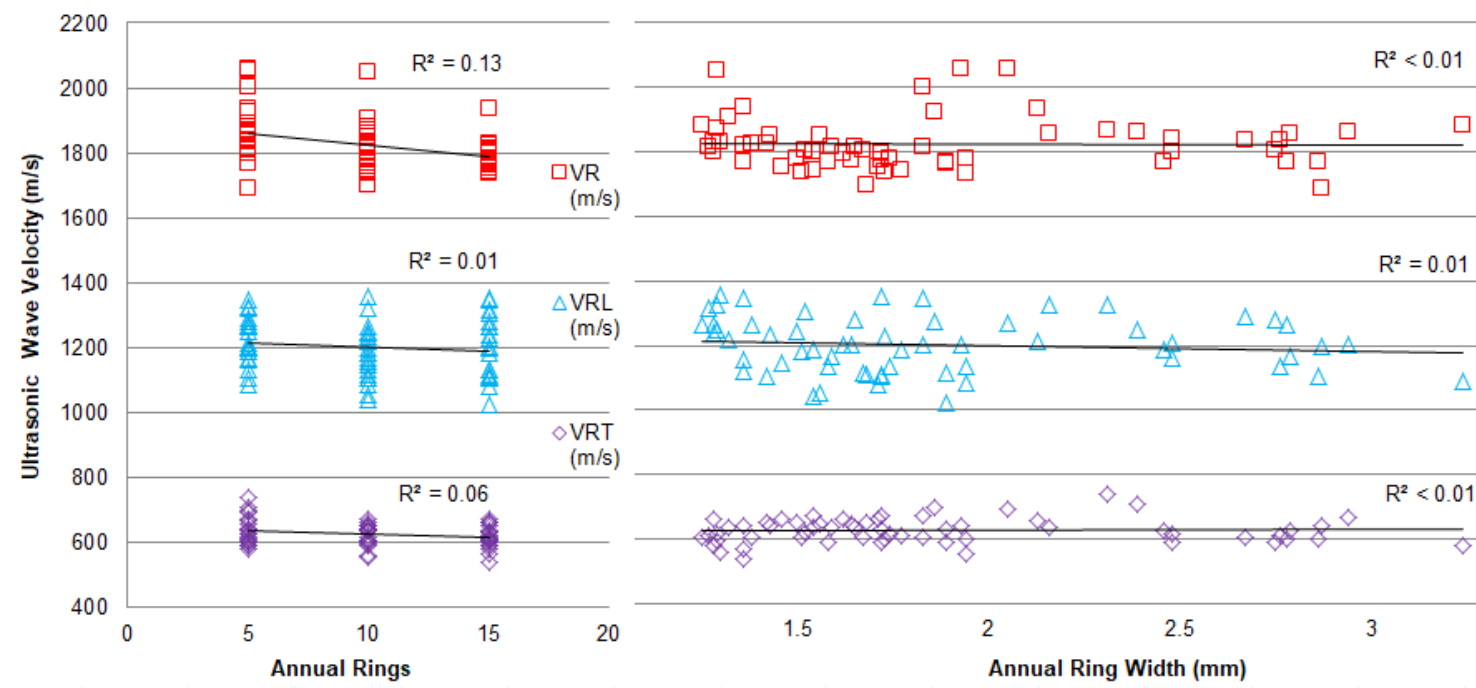

Fig. 5. The relationship between UWV and ARN or ARW for Black pine
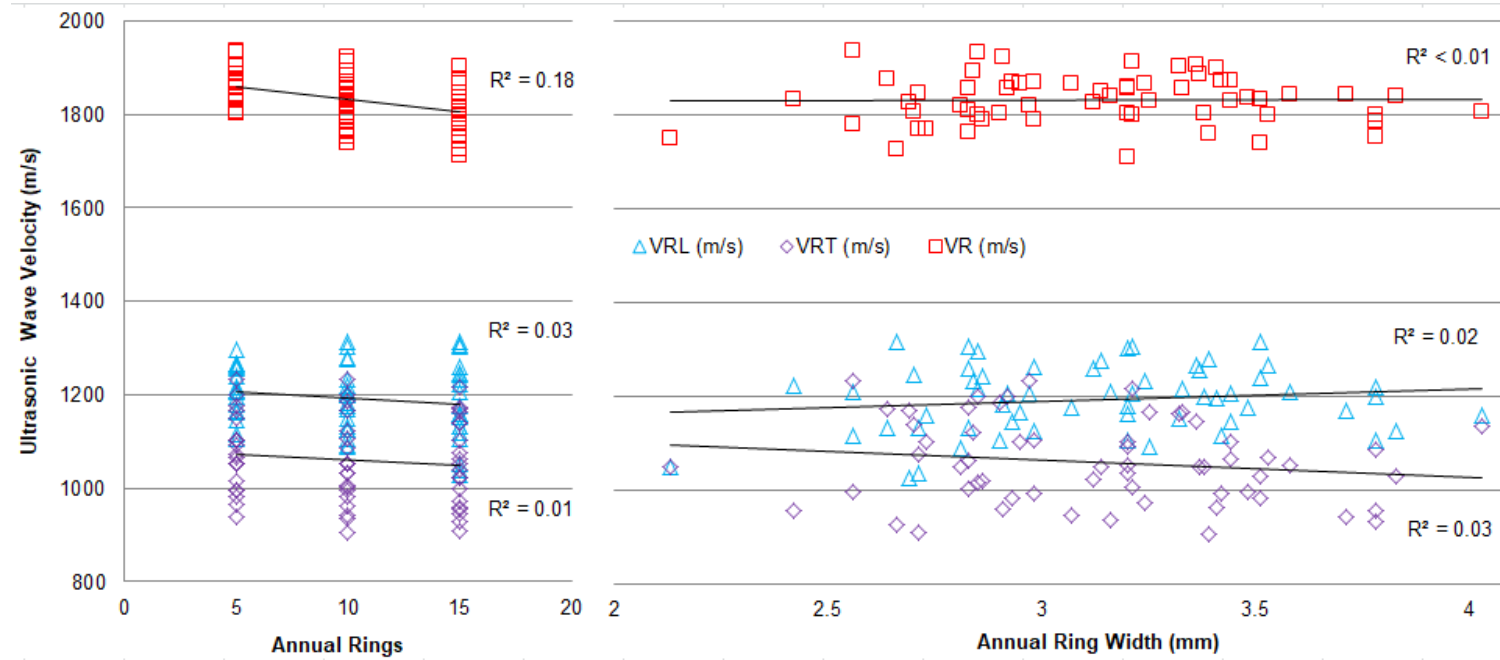

Fig. 6. The relationship between UWV and ARN or ARW for Cedar 
According to ANOVA results of linear regression (Table 5), only $V_{\mathrm{R}}$ of Scots pine, and $V_{\mathrm{R}}, V_{\mathrm{RL}}$, and $V_{\mathrm{RT}}$ of Red pine could be significantly $(\mathrm{P}<0.05)$ predicted by ARW. However, as highlighted before, not even half of the dependent variable can be predicted by ARW. Therefore, in general, models did not statistically significantly predict the dependent variables.

Table 5. ANOVA Results for ARW

\begin{tabular}{|c|c|c|c|c|c|c|c|c|}
\hline \multicolumn{9}{|c|}{ Linear Regression ANOVA for ARW } \\
\hline \multirow[b]{2}{*}{ Velocities } & \multicolumn{2}{|c|}{ Scots Pine } & \multicolumn{2}{|c|}{ Red Pine } & \multicolumn{2}{|c|}{ Black Pine } & \multicolumn{2}{|l|}{ Cedar } \\
\hline & $\mathrm{F}$ & Sig. & $\mathrm{F}$ & Sig. & $\mathrm{F}$ & Sig. & $\mathrm{F}$ & Sig. \\
\hline$V_{R}$ & 48.450 & 0.000 & 32.211 & 0.000 & 0.031 & 0.861 & 0.010 & 0.922 \\
\hline$V_{\text {RL }}$ & 0.427 & 0.516 & 21.232 & 0.000 & 0.713 & 0.402 & 1.300 & 0.259 \\
\hline$V_{\text {RT }}$ & 1.962 & 0.166 & 35.585 & 0.000 & 0.159 & 0.691 & 1.624 & 0.208 \\
\hline
\end{tabular}

It is unclear that the decrease tendency and severity in velocities (Table 1) are related to ARN, because only Scots pine and cedar woods presented consistent decreases with the increase in ARN. However, these decreases in these two species were not the highest among all. When the whole results were taken into consideration, the ARN and ARW are not the variables that can be associated to make a general expression for the variation of the longitudinal and transverse UWV in the radial direction of softwoods.

Measuring ARW using image analysis illustrates the amount of the latewood (LW) and earlywood (EW) that can be detected by the high-resolution images for high readability (Norell 2009). Capturing images by a digital camera is a fast method of illustration (Norell 2011), and, according to Maes et al. (2017), image analysis programs enable users to detect the ring boundaries manually or automatically. In this study, rings of the softwoods were characterized by high-resolution images and evaluated by computer software over the manually determined ring boundaries.

The differences between $V_{\mathrm{TR}}$ and $V_{\mathrm{RT}}$ are around 10 to $15 \%$ for the softwoods with pronounced AR structure (Bucur 1988). However, in this study, only $V_{\mathrm{RL}}$ and $V_{\mathrm{RT}}$ were measured, and such a comparison was not possible.

Yeh et al. (2007) evaluated the effects of detection types on the longitudinal UWV of Japanese cedar and Chinese fir with $9.3 \pm 4.3$ and $8.8 \pm 3.7 \mathrm{~mm}$ ARW, respectively. However, they did not investigate the relationship between the ARW and UWV that might provide a comparison opportunity with this study.

Lots of wood quality characteristics are tightly related to the ARW (Blass and Sandhaas 2017), and density is one of the most important determinants of wood characteristics. For example, density and mechanical features are oppositely proportional to the ARW for coniferous (Bektas et al. 2003). Furthermore, studies generally investigated the relationship between density and ARW. According to Baar et al. (2012), velocity and density are dependent variables for the acoustic properties of wood. Density is the second main variable that influences the ultrasound velocity (Calegari et al. 2011). Furthermore, density is one of the essential factors that influences the UWV in solids (Tomppo 2013). However, there is no consensus on the effect of density on the UWV in wood. For example, positive (Baar et al. 2012; de Oliveira and Sales 2006; Y1lmaz Aydın and Aydın 2018a,b,c), neutral (Ilic 2003; Mishiro 1996; Peng et al. 2016), and negative (Bucur and Chivers 1991; Hasegawa et al. 2011) influences were reported. As can be seen in Table 1, variations in 
the densities were not extremely high and ranged from 1.87 to 5.88. Furthermore, means were in harmony with the reported values.

Density differences between the denser LW and less dense EW due to structural properties such as thick or thin-walled cells are one of the responsible factors for property changes, respectively (Zisi 2015). According to Feeney et al. (1998), density alterations within the AR are composed of denser LW, and velocity variation within the wood species occurs due to less dense EW. Furthermore, EW share in softwoods is typically five times higher than LW, and this causes significant changes in the stiffness of wood (Zisi 2015). Also, length of tracheid varies in EW and LW (Schubert 2007). In addition, repetitive or cyclic formation of the EW and LW structures in a ring from pith to bark compose a periodic structure that produces bands that allow or block the waves (McIntyre and Woodhouse 1986). This phenomenon was also mentioned by Bucur et al. (1994) and (Feeney et al. 1998). Moreover, wave propagation through radial and tangential directions is complicated due to stop bands caused by inhomogeneity (Bucur 2003; Tippner et al. 2013). Sonic band gaps may be raised due to inhomogeneity caused by a periodic array of annual rings as little as five (James et al. 1995), and a strong potential scattering source within the material along the radial direction is provided by a sharp impedance step between EW and LW (Feeney et al. 1998). Band filtering alteration due to interaction of microstructure and wavelength (Bucur 2006) is another important issue for the ultrasonic wave propagation in solid wood. Furthermore, although higher frequencies provide acceptable results, measurements significantly vary from sample to sample with variations in ring spacing and other physical properties of wood (McIntyre and Woodhouse 1986). As mentioned in the experimental section, interaction between the frequency of the longitudinal wave and ARW in terms of the pass and stop bands was not evaluated. Indeed, using wide-range frequencies may provide valuable data for comparisons. However, neither density variations within and between the rings nor propagation of different frequencies were the main motivations of this study, and the issue needs to be addressed in a future study.

High-attenuation materials such as wood (Tiitta et al. 2020) make measurements and evaluation complicated due to their complex orthotropic nature. According to Saadatnia et al. (2015), successful evaluation of wood properties becomes more difficult when the age and diameter of a tree increase because of increased inhomogeneity by adding annual growth rings. This development produces mature wood that has longer elements, thicker walls, as well as higher density (Saadatnia et al. 2015).

According to Hasegawa et al. (2011) wave velocity in softwood increases from pith to bark, and fiber orientation, wall thickness, and microfibril angle are the three essential factors that influence the acoustic properties of wood. However, annual ring curvature (ARC) is just as influential as when waves propagate through the tangential direction. Various studies dealt with the effect of ARC or inclination on ultrasonic wave propagation. For example, Jordan et al. (1998) highlighted the influences of ARC and repetition of the $\mathrm{AR}$ on the wave propagation in tangential and radial directions, respectively. As can be seen in Fig. 1 and Table 1, samples used in this study were prepared from outer parts of the sapwood sections of laths to minimize the effect of ARC on UWV and also to obtain lesser variations, respectively.

Bucur (2006) reported that $V_{\mathrm{LL}}$ and $V_{\mathrm{TT}}$ in LW of spruce were $13.14 \%$ and $38.23 \%$ higher than EW, respectively. Furthermore, both values were lower than solid wood (a complete annual ring), but the $V_{\text {TT }}$ of LW (-2.2\%) was closer to that of solid wood. The author reported that $V_{\mathrm{LL}}$ of spruce and curly maple were reduced with the increase in ARW.

Aydın (2022). "Ultrasonic waves in wood annual rings," BioResources 17(1), 1745-1763. 1755 
However, ARW and ARC have no influence on the $V_{\mathrm{RT}}$ of spruce since the direction of propagation is radial. On the contrary, the effect of the AR on the $V_{\text {TR }}$ of spruce is evident. For this study, the maximum decrease in UWV was 4\%, and according to ANOVA results (except longitudinal wave velocity $V_{\mathrm{R}}$ ) results agree with this expression.

Kránitz et al. (2014) correlated the ARW of aged Norway spruce to dynamic elastic moduli and shear moduli using $2.25 \mathrm{MHz}$ longitudinal and $1 \mathrm{MHz}$ transverse ultrasonic waves. Contrary to the results of this study, the authors reported that ARW significantly affected the data of the samples, and changes in the velocity were associated with changes in cell wall structure due to aging.

The complex structure of wood anatomy plays an essential role in the propagation of ultrasonic waves through the axes. Ray and tracheid are two main tissues that form the structure of conifers, and rays extend along the radial direction of the wood. Besides, resin ducts (not present in some conifer species) elongate through radial and longitudinal directions. Therefore, radial and tangential diameters of cell and lumens, radial and tangential thickness of double walls, and cross-sectional areas of lumen, wall, and cell (Cuny et al. 2014) properties can be assumed as the essential responsible factors that influence the UWV in the radial direction of the wood. Furthermore, rays and resin ducts may influence the refraction, reflection, diffraction, scattering, and attenuation for the propagation of the ultrasonic wave in wood. Also, many evergreen gymnosperms present anatomical characteristics within the ARs that separate the EW (relatively large diameters tracheids) from the neighboring LW (dense, small-diameter tracheids) tissues (Szejner et al. 2016). These cyclic alterations in sequenced ARs may also influence wave propagation.

\section{CONCLUSIONS}

1. There is a decreasing tendency in the ultrasonic wave (UWV) velocities with the increase in annual ring number (ARN). However, this tendency is not stable within and between the species. For example, only UWV of Scots pine and cedar were gradually decreased with the increase in ARN. Furthermore, the longitudinal wave velocity of red pine was decreased, and it scarcely any surpassed the initial value with the increase in ARN. Duncan's test results showed that an increase in ARN did not cause statistically significant differences between the average values of velocities except cedar and black pine woods. However, these differences were not observed when ARN increased from 10 to 15 .

2. Except for $V_{\mathrm{R}}$ of Scots pine, and $V_{\mathrm{R}}, V_{\mathrm{RL}}$, and $V_{\mathrm{RT}}$ of Red pine, the regression models explained that there were no statistically significant relations between independent and dependent variables due to negligible percent of the variance in the response variable can be explained by the explanatory variables. Therefore, a general assessment of the barrier effect of ARW against the UWV may be inaccurate.

3. When opposite outcomes of the ARW and ARN effects on the UWV (particularly for $V_{\mathrm{R}}$,) for species are taken into consideration, no meaningful expression can be made, and it's thought that these diffractions might have occurred casually. The reasons for these behaviors in the longitudinal wave propagation should be determined by further investigations. 
4. The current study was limited to evaluating the effects of the same number of annual rings using contact-type transducers propagating certain frequencies through small clear samples in the direct propagation method. However, different propagation methods such as air-coupled, pulse-echo, etc., frequencies such as $\mathrm{kHz}$, transducers, and tools, and larger sample sizes through the radial direction and more annual rings can be used to provide valuable data for comparison.

\section{ACKNOWLEDGMENTS}

The author is grateful to Assoc. Prof. Tuğba YILMAZ AYDIN, and Isparta University of Applied Sciences, Faculty of Forestry, Department of Wood Mechanics and Technology.

\section{REFERENCES CITED}

Adamopoulos, S., Milios, E., Doganos, D., and Bistinas, I. (2009). "Ring width, latewood proportion and dry density in stems of Pinus brutia Ten.," European Journal of Wood and Wood Products 67(4), 471-477. DOI: 10.1007/s00107-009-0345-X

Akar, S. (2017). Determination of the Elastic Constants of Scots pine (Pinus sylvestris L.), Master's Thesis, Süleyman Demirel University, Isparta, Turkey.

Akkemik, Ü. (2003). "Tree rings of Cedrus libani at the northern boundary of its natural distribution,” IAWA Journal, 24(1), 63-73. DOI: 10.1163/22941932-90000321

Ansell, M. P. (2015). "Wood microstructure - A cellular composite," in: Wood Composites, M. Ansell (ed.), WoodHead Publishing, Cambridge, UK. DOI: 10.1016/B978-1-78242-454-3.00001-9

Aydın, M., and Ciritcioglu, H. (2018). "Shear moduli prediction of Calabria pine (Pinus brutia Ten.) using ultrasonic wave propagation," Düzce University Journal of Science and Technology 6(1), 176-187. DOI: 10.29130/dubited.371435

Aydın, M., and Yılmaz Aydın, T. (2018). "Shear moduli determination of naturally aged black pine wood," in: International Forest Products Congress, Karadeniz Technical University, Trabzon, pp. 791-795.

Aydın, M., and Yılmaz Aydın, T. (2020). "Moisture dependent elastic properties of naturally aged black pine wood," Construction and Building Materials 262, article no. 120752. DOI: 10.1016/j.conbuildmat.2020.120752

Baar, J., Tippner, J., and Gryc, V. (2012). "The influence of wood density on longitudinal wave velocity determined by the ultrasound method in comparison to the resonance longitudinal method," European Journal of Wood and Wood Products 70(5), 767769. DOI: $10.1007 / \mathrm{s} 00107-011-0550-2$

Bachtiar, E. V., Sanabria, S. J., Mittig, J. P., and Niemz, P. (2017). "Moisture-dependent elastic characteristics of walnut and cherry wood by means of mechanical and ultrasonic test incorporating three different ultrasound data evaluation techniques," Wood Science and Technology, 51(1), 47-67. DOI: 10.1007/s00226-016-0851-z

Bektas, I., Hakk Alma, M., As, N., and Gundogan, R. (2003). "Relationship between site index and several mechanical properties of Turkish calabrian pine (Pinus brutia Ten.)," Forest Products Journal, 53(2), 27-31.

Bendtsen, B. A. (1978). "Properties of wood from improved and intensively managed 
trees," Forest Products Journal 28(10), 61-72.

Bergander, A., and Salmén, L. (2000). "Variations in transverse fibre wall properties:

Relations between elastic properties and structure," Holzforschung 54(6), 654-660.

DOI: $10.1515 /$ HF.2000.110

Berndt, H., and Johnson, G. C. (1995). "Examination of wave propagation in wood from a microstructural perspective," in: Review of Progress in Quantitative Nondestructive Evaluation, pp. 1661-1668. DOI: 10.1007/978-1-4615-1987-4_213

Blass, H. J., and Sandhaas, C. (2017). Timber engineering: Principles for design, IFAC Proceedings Volumes, KIT Scientific Publishing. DOI: 10.5445/KSP/1000069616

Brancheriau, L., Ghodrati, A., Gallet, P., Thaunay, P., and Lasaygues, P. (2012). "Application of ultrasonic tomography to characterize the mechanical state of standing trees (Picea abies)," in: Journal of Physics: Conference Series, pp. 1-13. DOI: $10.1088 / 1742-6596 / 353 / 1 / 012007$

Bucur, V. (1988). "Wood structural anisotropy estimated by acoustic invariants," IAWA Bulletin 9(1), 67-74. DOI: 10.1163/22941932-90000471

Bucur, V. (2003). Nondestructive Characterization and Imaging of Wood, SpringerVerlag Berlin Heidelberg, Heidelberg.

Bucur, V. (2006). Acoustics of wood, The Acoustics of Wood, Springer-Verlag Berlin Heidelberg, Heidelberg. DOI: 10.1201/9780203710128

Bucur, V., and Chivers, R. C. (1991). "Acoustic properties and anisotropy of some Australian wood species," Acustica 75(1), 69-74.

Bucur, V., Herbe, C., and Nosei, G. (1994). "Annual ring characteristics of Pinus taeda measured by ultrasonic and X-ray techniques," IAWA Bulletin 15(2), 121-132. DOI: 10.1163/22941932-90001351

Bucur, V., and Kazemi-Najafi, S. (2011). "Delamination detection in wood - Based composites panel products using ultrasonic techniques," in: Delamination in Wood, Wood Products and Wood-Based Composites, 307-351. DOI: 10.1007/978-90-4819550-3_16

Büyüksari, Ü., As, N., and Dündar, T. (2017). "Mechanical properties of earlywood and latewood sections of scots pine wood," BioResources 12(2), 4004-4012. DOI: 10.15376/biores. 12.2.4004-4012

Calegari, L., Gatto, D. ., and Stangerlin, D. (2011). "Influence of moisture content, specific gravity and specimen geometry on the ultrasonic pulse velocity in Eucalyptus grandis Hill ex Maiden wood," Brazilian Journal of Wood Science 2(2), 64-74. DOI: 10.12953/2177-6830.v02n02a01

Carrer, M. (2011). "Individualistic and time-varying tree-ring growth to climate sensitivity,” PLOS ONE 6(7), 8. DOI: 10.1371/journal.pone.0022813

Cuny, H. E., Rathgeber, C. B. K., Frank, D., Fonti, P., and Fournier, M. (2014). "Kinetics of tracheid development explain conifer tree-ring structure," New Phytologist 203(4), 1231-1241. DOI: 10.1111/nph.12871

Dackermann, U., Crews, K., Kasal, B., Li, J., Riggio, M., Rinn, F., and Tannert, T. (2014). "In situ assessment of structural timber using stress-wave measurements," Materials and Structures/Materiaux et Constructions 47(5), 787-803. DOI: 10.1617/s11527-013-0095-4

Dackermann, U., Elsener, R., Li, J., and Crews, K. (2016). “A comparative study of using static and ultrasonic material testing methods to determine the anisotropic material properties of wood," Construction and Building Materials 102, 963-976. DOI: 10.1016/j.conbuildmat.2015.07.195 
de Oliveira, F. G. R., and Sales, A. (2006). "Relationship between density and ultrasonic velocity in Brazilian tropical woods," Bioresource Technology 97(18), 2443-2446. DOI: 10.1016/j.biortech.2005.04.050

Dogan, M., and Kose, N. (2019). "Influence of climate on radial growth of Black pine on the mountain regions of Southwestern Turkey," Plants, 8(276), 1-15.

Doğan, M., and Köse, N. (2015). "Four new tree-ring chronologies from old black pine forests of Sandiras Mountain (Mugla, Turkey)," Journal of the Faculty of Forestry Istanbul University, 65(2), 1-16.

Dündar, T. (2005). The effect of different silvicultural treatments on some technological properties of Scotch Pine (Pinus sylvestris L.) wood in Turkey, Ph.D. Dissertation, İstanbul University, İstanbul.

Fabisiak, E., and Fabisiak, B. (2021). "Relationship of tracheid length, annual ring width, and wood density in Scots pine (Pinus sylvestris L.) trees from different social classes of tree position in the stand," BioResources 16(4), 7492-7508. DOI: 10.15376/biores.16.4.7492-7508

Feeney, F. E., Chivers, R. C., Evertsen, J. A., and Keating, J. (1998). "The influence of inhomogeneity on the propagation of ultrasound in wood," Ultrasonics 36(1-5), 449453. DOI: $10.1016 / \mathrm{S} 0041-624 \mathrm{X}(97) 00066-8$

Gonçalves, R., Trinca, A., Cerri, D. G., and Pellis, B. (2011). "Elastic constants of wood determined by ultrasound wave propagation," in: $17^{\text {th }}$ Symposium Nondestructive Testing of Wood, University of West Hungary, Sopron, 435-441.

Gonçalves, R., Trinca, A. J., and Pellis, B. P. (2014). "Elastic constants of wood determined by ultrasound using three geometries of specimens," Wood Science and Technology, 48(2), 269-287. DOI: 10.1007/s00226-013-0598-8

Gros, X. E. (1997). "A Bayesian statistical inference approach to the non-destructive inspection of composite material," in: NDT Data Fusion, X.E. Gros (ed.), Arnold, London. DOI: 10.1016/b978-034067648-6/50007-4

Güntekin, E., and Yilmaz Aydın, T. (2016). "Determination of elastic constants for Anatolian black pine wood using ultrasound," in: WCTE 2016 - World Conference on Timber Engineering, Vienna University of Technology, Vienna, pp. 976-981.

Güntekin, E., Y1lmaz Aydin, T., and Niemz, P. (2015a). "Prediction of compression properties in three orthotropic directions for some important Turkish wood species using ultrasound," BioResources 10(4), 7252-7262. DOI: 10.15376/biores.10.4.72527262

Güntekin, E., Y1lmaz Aydın, T., and Niemz, P. (2015b). 'Determination of Young's Modulus in three orthotropic directions for Calabrian pine and Taurus cedar using ultrasound and digital image correlation (DIC)," in: 3rd. Int. Symposium on Innovative Technologies in Engineering and Science, Valecia.

Haneca, K., Čufar, K., and Beeckman, H. (2009). "Oaks, tree-rings and wooden cultural heritage: A review of the main characteristics and applications of oak dendrochronology in Europe," Journal of Archaeological Science 36(1), 1-11. DOI: 10.1016/j.jas.2008.07.005

Hasegawa, M., Mori, M., and Matsumura, J. (2016). "Non-contact velocity measurement of japanese cedar columns using air-coupled ultrasonics," World Journal of Engineering and Technology 4(1), 45-50. DOI: 10.4236/wjet.2016.41005

Hasegawa, M., Takata, M., Matsumura, J., and Oda, K. (2011). "Effect of wood properties on within-tree variation in ultrasonic wave velocity in softwood," Ultrasonics 51(3), 296-302. DOI: 10.1016/j.ultras.2010.10.001 
Hering, S., Keunecke, D., and Niemz, P. (2012). "Moisture-dependent orthotropic elasticity of beech wood," Wood Science and Technology, 46(5), 927-938. DOI: 10.1007/s00226-011-0449-4

Ilic, J. (2003). "Dynamic MOE of 55 species using small wood beams," Holz als Rohund Werkstoff 61(3), 167-172. DOI: 10.1007/s00107-003-0367-8

Jackson, J. B., Mourou, M., Labaune, J., Whitaker, J. F., Duling, I. N., Williamson, S. L., Lavier, C., Menu, M., and Mourou, G. A. (2009). "Terahertz pulse imaging for treering analysis: A preliminary study for dendrochronology applications," Measurement Science and Technology 20(7), article no. 075502. DOI: 10.1088/09570233/20/7/075502

James, R., Woodley, S. M., Dyer, C. M., and Humphrey, V. F. (1995). "Sonic bands, bandgaps, and defect states in layered structures - Theory and experiment," Journal of the Acoustical Society of America, 97(4), 2041-2047. DOI: 10.1121/1.41199

Jordan, R., Feeney, F., Nesbitt, N., and Evertsen, J. A. (1998). "Classification of wood species by neural network analysis of ultrasonic signals," Ultrasonics 36(1-5), 219222. DOI: $10.1016 / \mathrm{S} 0041-624 \mathrm{X}(97) 00148-0$

Kantarci, M. D., Kilci, M., Akbin, G., Sayman, M., and Bircan, E. (2013). "Relationship between the annual ring widths of an old Black pine (Pinus nigra Arnold subsp. pallasiana) tree and dry climate periods of Hodul Mountain forest remnants in Ürgup/Akcaoren - Turkey," Conference: $6^{\text {th }}$ Atmospheric Science Symposium (ATMOS-2013), 15.

Kharrat, W., Koubaa, A., Khlif, M., and Bradai, C. (2019). "Intra-ringwood density and dynamic modulus of elasticity profiles for black spruce and jack pine from X-ray densitometry and ultrasonicwave velocity measurement," Forests 10(7), 569. DOI: 10.3390/f10070569

Knapic, S., Louzada, J. L., Leal, S., and Pereira, H. (2007). "Radial variation of wood density components and ring width in cork oak trees," Annals of Forest Science 64(2), 211-218. DOI: 10.1051/forest:2006105

Köse, N., Akkemik, ünal, Dalfes, H. N., Özeren, M. S., and Tolunay, D. (2012). “Treering growth of Pinus nigra Arn. subsp. pallasiana under different climate conditions throughout western Anatolia," Dendrochronologia 30(4), 295-301. DOI: 10.1016/j.dendro.2012.04.003

Kránitz, K., Deublein, M., and Niemz, P. (2014). "Determination of dynamic elastic moduli and shear moduli of aged wood by means of ultrasonic devices," Materials and Structures/Materiaux et Constructions 47(6), 925-936. DOI: 10.1617/s11527013-0103-8

Krause, M., Dackermann, U., and Li, J. (2015). "Elastic wave modes for the assessment of structural timber: ultrasonic echo for building elements and guided waves for pole and pile structures," Journal of Civil Structural Health Monitoring 5(2), 221-249. DOI: $10.1007 / \mathrm{s} 13349-014-0087-2$

Luis Gómez-Royuela, J., Majano-Majano, A., José Lara-Bocanegra, A., and Reynolds, T. P. S. (2021). "Determination of the elastic constants of thermally modified beech by ultrasound and static tests coupled with 3D digital image correlation," Construction and Building Materials 302. DOI: 10.1016/j.conbuildmat.2021.124270

Maes, S. L., Vannoppen, A., Altman, J., Van den Bulcke, J., Decocq, G., De Mil, T., Depauw, L., Landuyt, D., Perring, M. P., Van Acker, J., Vanhellemont, M., and Verheyen, K. (2017). "Evaluating the robustness of three ring-width measurement methods for growth release reconstruction," Dendrochronologia 46, 67-76. DOI: 
10.1016/j.dendro.2017.10.005

Martinez, R., Bobadilla, I., Iñiguez, G., Arriaga, F., Esteban, M., and Hermoso, E. (2010). "Assessment of decay in existing timber members by means of wave velocity perpendicular to the grain," in: $11^{\text {th }}$ World Conference on Timber Engineering 2010, WCTE 2010, pp. 1471-1475.

McIntyre, M. E., and Woodhouse, J. (1986). "On measuring wood properties, Part 3," Journal of Catgut Acoustic Society 45, 14-24.

Mederski, P., Bembenek, M., Karaszewski, Z., Giefing, D., Tomczak, A., and Wegiel, A. (2013). "Annual rings characteristic of Scots pine (Pinus sylvestris L.) wood from seedling seed orchard," Annals of Warsaw University of Life Sciences - SGGW. Forestry and Wood Technology, 83.

Mishiro, A. (1996). "Effect of density on ultrasonic velocity in wood," Mokuzai Gakkaishi 42(9), 887-894.

Mori, M., Kuhara, S., Kobayashi, K., Suzuki, S., Yamada, M., and Senoo, A. (2019). "Non-destructive tree-ring measurements using a clinical 3T-MRI for archaeology," Dendrochronologia 57, article no. 125630. DOI: 10.1016/j.dendro.2019.125630

Niemz, P., Amman, S., Rohner, T., and Pichelin, F. (2017). "Mechanical performance of structural hardwood elements," in: $7^{\text {th }}$ Forum International Bois Construction, Forum International Bois Construction, Nancy, pp. 1-10.

Norell, K. (2009). "An automatic method for counting annual rings in noisy sawmill images," in: Lecture Notes in Computer Science (including subseries Lecture Notes in Artificial Intelligence and Lecture Notes in Bioinformatics). DOI: 10.1007/978-3642-04146-4_34

Norell, K. (2011). "Automatic counting of annual rings on Pinus sylvestris end faces in sawmill industry," Computers and Electronics in Agriculture 75(2), 231-237. DOI: 10.1016/j.compag.2010.11.005

Öktem, E., and Sözen, R. (1992). "Sedir odununun anatomik ve teknolojik özellikleri ile kullanım yerleri,” in: Sedir, Ü. Eler, ed., Ormancılık Araştırma Enstitüsü, Ankara, 287-297.

Özel, H. B., Yaman, B., and Varol, T. (2021). "The effect of climate on radial growth of scots pine (Pinus sylvestris L.) in a coastal mixed stand in kapisuyu, Bartin, Turkey," Indonesian Journal of Forestry Research 8(2), 187-197. DOI: 10.20886/ijfr.2021.8.2.187-197

Peng, H., Jiang, J., Zhan, T., and Lü, J. (2016). "Influence of density and moisture content on ultrasound velocities along the longitudinal direction in wood," Linye Kexue/Scientia Silvae Sinicae 52(10), 117-124. DOI: 10.11707/j.10017488.20161015

Perlin, L. P., Pinto, R. C. de A., and Valle, Â. do. (2019). "Ultrasonic tomography in wood with anisotropy consideration," Construction and Building Materials 229, article no. 116958. DOI: 10.1016/j.conbuildmat.2019.116958

Saadatnia, M., Pourtahmasi, K., Moradian, M. H., and Poursartip, L. (2015). "Compression wood quality assessment with different ultrasound wave parameters in radial direction of spruce disks," in: International Symposium Non-Destructive Testing in Civil Engineering (NDT-CE), Berling, pp. 1047-1056.

Schubert, S. (2007). Acousto-Ultrasound Assessment of Inner Wood-Decay in Standing Trees: Possibilities and Limitations, Ph.D. Dissertation, ETHZ, Zurich, Swiss.

Schweingruber, F. H. (1988). Tree Rings Basics and Applications of Dendrochronology, Kluwer Academic Publishers, Dordrecht. DOI: 10.1007/978-94-009-1273-1 
Sensuła, B., Wilczyński, S., Monin, L., Allan, M., Pazdur, A., and Fagel, N. (2017). "Variations of tree ring width and chemical composition of wood of pine growing in the area nearby chemical factories," Geochronometria, 44(1), 226-239. DOI: 10.1515/geochr-2015-0064

Shishkova, V., and Panayotov, M. (2013). "Climate-growth relationship of Pinus nigra tree-ring width chronology from the rhodope mountains, Bulgaria," Bulgarian Journal of Agricultural Science 19(SUPPL. 2), 225-228.

Speer, J. H. (2012). Fundamentals of Tree-ring Research, University of Arizona Press, Tucson, AZ, USA. DOI: 10.1002/gea.20357

Szejner, P., Wright, W. E., Babst, F., Belmecheri, S., Trouet, V., Leavitt, S. W., Ehleringer, J. R., and Monson, R. K. (2016). "Latitudinal gradients in tree ring stable carbon and oxygen isotopes reveal differential climate influences of the North American Monsoon System," Journal of Geophysical Research: Biogeosciences, 121(7), 1978-1991. DOI: 10.1002/2016JG003460

Tiitta, M., Tiitta, V., Gaal, M., Heikkinen, J., Lappalainen, R., and Tomppo, L. (2020). "Air-coupled ultrasound detection of natural defects in wood using ferroelectret and piezoelectric sensors," Wood Science and Technology 54(4), 1051-1064. DOI: 10.1007/s00226-020-01189-y

Tippner, J., Gryc, V., and Baar, J. (2013). "The relation of fibre length and ray dimensions to sound propagation velocity in wood of selected tropical hardwoods," IAWA Journal 34(1), 49-60. DOI: 10.1163/22941932-00000005

Tolunay, D. (2003). "Air pollution effects on annual ring widths of forest trees in mountainous land of Izmir (Turkey)," Water, Air, and Soil Pollution: Focus, 3(5-6), 227-242. DOI: 10.1023/A:1026017515151

Tomppo, L. (2013). Novel Applications of Electrical Impedance and Ultrasound Methods for Wood Quality Assessment, Ph.D Dissertation, University of Eastern Finland, Kuopio.

Trouillier, M., van der Maaten-Theunissen, M., Harvey, J. E., Würth, D., Schnittler, M., and Wilmking, M. (2018). "Visualizing individual tree differences in tree-ring studies," Forests 9(4), 1-14. DOI: 10.3390/f9040216

TS 2472. (2005). Wood - Determination of Density for Physical and Mechanical Tests, Wood, Sawlogs and Sawn Timber (ICS 79.040), Ankara.

Vázquez, C., Gonçalves, R., Bertoldo, C., Baño, V., Vega, A., Crespo, J., and Guaita, M. (2015). "Determination of the mechanical properties of Castanea sativa Mill. using ultrasonic wave propagation and comparison with static compression and bending methods," Wood Science and Technology, 49(3), 607-622. DOI: 10.1007/s00226015-0719-7

Yeh, M. C., Liu, C. K., and Lin, Y. L. (2007). "Effects of ultrasonic detection modes on the longitudinal ultrasonic wave transmission in domestic plantation lumber," Taiwan Journal of Forest Science 22(1), 57-68. DOI: 10.7075/TJFS.200703.0057

Yilmaz Aydın, T., and Aydın, M. (2018a). "Effect of density and propagation length on ultrasonic longitudinal wave velocity in some important wood species grown in Turkey," Turkish Journal of Forestry 19(4), 413-418. DOI: 10.18182/tjf.459005

Y1lmaz Aydın, T., and Aydın, M. (2018b). "Relationship between density or propagation length and ultrasonic wave velocity in cedar (Cedrus libani) wood," in: International Science and Technology Conference, Paris, pp. 531-535.

Yilmaz Aydın, T., and Aydın, M. (2018c). "Relationship between density or propagation length and ultrasonic wave velocity in sessile oak (Quercus petraea) wood," in: $4^{\text {th }}$ 
Int. Conf. on Advances in Mechanical Enginering, Y1ldız Technical University, İstanbul, pp. 1708-1712.

Yılmaz Aydın, T., and Küçükkose, A. (2020). "Ultrasonic testing and evaluation of moisture dependent elastic properties of fir wood," Materials Testing 62(10), 10591064.

Zisi, A. (2015). Relationship Between Wood Density and Ultrasound Propagation Velocity: A Non-Destructive Evaluation of Waterlogged Archaeological Wood State of Preservation Based on its Underwater Acoustic Properties, Ph.D. Dissertation, University of Southampton, Southampton.

Article submitted: October 31, 2021; Peer review completed: December 19, 2021;

Revised version received and accepted: January 14, 2022; Published: January 24, 2022.

DOI: 10.15376/biores.17.1.1745-1763 